\title{
4. Ocena kondycji finansowej firmy logistycznej na przykładzie przedsiębiorstwa $X$
}

\author{
Łukasz Borowiecki *
}

\subsection{Wstęp}

Przełom cywilizacyjny, którego jesteśmy świadkami na początku XXI w., nierozerwalnie wiąże się z tworzeniem gospodarki opartej na wiedzy. Kluczową rolę zaczyna odgrywać informacja, która staje się istotnym zasobem niematerialnym organizacji. Dzisiaj wręcz mówi się, iż zarządzanie firmą to zarządzanie informacjami ${ }^{1}$. Podejmowanie trafnych i szybkich decyzji, zarówno strategicznych, jak i taktycznych, wymaga zatem stworzenia przesłanek informacyjnych. Każda firma, działając w coraz szybciej zmieniającym się otoczeniu i chcąc zdobyć przewagę konkurencyjna, zmuszona jest do stworzenia systemu informacyjnego. Ten ostatni obejmuje: pozyskiwanie informacji, ich przetwarzanie oraz analizowanie na użytek decyzji zarządczych.

Jedna z podstawowych funkcji przedsiębiorstwa, obok personalnej, marketingowej i produkcyjnej, jest funkcja finansowa. Cała działalność firmy znajduje swój końcowy efekt w wyniku finansowym. Informacji dla potrzeb zarządzania finansami dostarcza system rachunkowości przedsiębiorstwa. Częścią składową tego systemu jest analiza finansowa.

Problematyka niniejszego rozdziału mieści się w nurcie rozważań związanych z analizą finansowa. Celem opracowania jest podkreślenie roli informacji finansowych $w$ firmie, wskazanie źródeł informacji słu-

*Mgr Łukasz Borowiecki - Katedra Logistyki, Wydział Zarządzania Uniwersytetu Łódzkiego, ul. Matejki 22/26, 90-237 Łódź.

${ }^{1}$ Szerzej na ten temat piszą m.in.: B. Gregor, M. Stawiszyński, e-Commerce, Oficyna Wyd. Branta, Bydgoszcz 2002; J. Kisielnicki, Infrastruktura zarządzania - Polska w Europie, "Master of Business Administration" 2002, nr 1; B. Wawrzyniak, Od koncepcji do praktyki zarządzania wiedzą w przedsiębiorstwie, "Master of Business Administration" 2002, nr 1. 
żących do oceny jej kondycji finansowej oraz stosowanych w tym celu wskaźników.

Egzemplifikacją ogólnych rozważań literaturowych jest przeprowadzona analiza i ocena sytuacji majątkowo-finansowej wybranego przedsiębiorstwa z branży logistycznej. Firma ta udostępniła materiały źródłowe pod warunkiem, iż nie będzie ujawniona jej nazwa, stąd też w tekście oznaczono ją litera $X$. Wybór przedsiębiorstwa nie był przypadkowy. Sektor usług logistycznych odgrywa i będzie odgrywał w gospodarce coraz większą rolę. Region łódzki uznawany jest za centrum logistyczne Polski. Wynika to z jego położenia oraz z infrastruktury drogowej - tu przecinają się główne szlaki komunikacyjne z zachodu na wschód i z północy na południe kraju.

\subsection{Charakterystyka przedsiębiorstwa $X$}

Firma X powstała w 1990 r. jako niewielki rodzinny sklep, zajmujący się sprzedażą szerokiego asortymentu elementów elektronicznych do serwisu i drobnej produkcji². Po dwóch latach działalności zajęła się nowatorską, jak na ówczesne czasy, sprzedaża wysyłkową elementów i dostarczaniem katalogów oferowanych produktów. Wraz z rozwojem gospodarki krajów Europy Środkowej i Wschodniej firma pozyskiwała nowych klientów i wprowadzała nowe grupy produktów. Z czasem została w niej wprowadzona norma ISO 9001:2001 i sprzedaż poprzez stronę internetowa.

Co istotne, powstało nowe centrum logistyczne, dzięki któremu pojawiła się możliwość sprawnego i szybkiego dostarczania zamówionego towaru nie tylko do krajów Unii Europejskiej, lecz także do Rosji, Ukrainy czy krajów arabskich. Obecnie firma jest największym dystrybutorem elementów elektronicznych w Europie Środkowej i Wschodniej. Obsługuje kilkadziesiąt tysięcy firm w ponad 30 krajach i wysyła prawie 1000 paczek dziennie.

Wśród oferowanych produktów znajduja się wyroby większości istotnych producentów komponentów elektronicznych. W zespole pracuje kilkudziesięciu inżynierów z dziedziny elektroniki, elektromechaniki i automatyki, a także konsultantów gotowych służyć klientom rada i informacją. Bardzo istotnym elementem działalności jest strona inter-

${ }^{2}$ Informacje ze strony internetowej firmy $\mathrm{X}$. 
netowa, przy pomocy której wielu klientów nie tylko dokonuje zakupów, lecz także uzyskuje istotne informacje.

Firma ma następujące działy sprzedaży:

- dział sprzedaży katalogowej,

- dział sprzedaży przemysłowej,

- dział sprzedaży dystrybucyjnej,

- dział eksportu,

- dział sprzedaży internetowej.

Firma oferuje:

- 50000 produktów dostępnych w magazynie,

- katalogi, płyty CD i serwis internetowy zawierający zdjęcia, parametry i opisy oferowanych produktów,

- odpowiedni poziom obsługi, gdyż firma od 1998 r. wdrożyła system nadzoru jakości ISO 9001:2001,

- dostawy w ciaggu jednego dnia roboczego na terenie Polski (jeśli towar znajduje się w magazynie, a zamówienie zostało złożone do godziny 17:00),

- dostawy w ciaggu 48-72 godzin na terenie krajów Unii Europejskiej,

- informację online (w czasie rzeczywistym) o stanach magazynowych i cenach na stronie internetowej,

- internetowy system zamawiania i wyszukiwania produktów,

- dostawy małych i hurtowych ilości produktów,

- ceny uzależnione od ilości zamawianego towaru,

- dogodne formy płatności,

- dostarczenie niektórych produktów spoza stałej oferty bez dodatkowych opłat,

- bezpłatne dostarczenie katalogów i dokumentacji technicznej oferowanych produktów,

- kompletowanie dostaw i zabezpieczenie odpowiednich stanów magazynowych,

- dla klientów w Czechach, Niemczech, Słowacji, Rumunii i na Węgrzech możliwość płacenia na konta w walutach narodowych ${ }^{3}$.

Firma posiada przedstawicielstwo w Czechach, na Węgrzech, Słowacji i w Niemczech.

${ }^{3}$ Informacje ze strony internetowej firmy X. 


\subsection{Wstępna analiza sprawozdań finansowych}

\subsubsection{Analiza struktury i dynamiki bilansu}

Wstępna analiza bilansu została wykonana na podstawie bilansu analitycznego. Badanie bilansu przeprowadza się w ujęciu poziomym i pionowym. Bilans analityczny spółki X prezentuja tabele 6 i 7.

$Z$ analizy bilansu wynika, że w 2008 r. nastapił wzrost wartości majatku w porównaniu do roku ubiegłego o 27,2\%. W tym okresie majatek trwały rósł wolniej $(19,6 \%)$ aniżeli majatek ogółem, stąd też zmniejszył się jego udział w strukturze majątku z 21,33 do 20,05\%. W majatku trwałym dominująca pozycję stanowiły rzeczowe aktywa trwałe, których udział w majątku trwałym w 2008 r. wynosił 94,4\%. Aktywa obrotowe wzrosły szybciej $(29,3 \%)$ aniżeli aktywa ogółem, stąd ich udział w strukturze majatku wzrósł o 1,28 punktu procentowego. W majątku obrotowym znacznie wzrosły zapasy $(37,8 \%)$, a ich udział w strukturze majątku ogółem wzrósł o 4,08\%, co nie zasługuje na pozytywną ocenę. Pozytywnie należy ocenić wolniejszy wzrost należności $(14,1 \%)$ aniżeli wzrost sprzedaży $(17,9 \%)$, co oznacza poprawę ich windykacji.

W omawianym okresie nastapił dość wysoki wzrost kapitałów własnych $(41,1 \%)$, a w szczególności kapitału zapasowego. Udział kapitałów własnych w finansowaniu majątku zwiększył się z 60,95 do 67,60\%, co oznacza wzrost niezależności finansowej. W związku z tym uległ zmniejszeniu udział kapitałów obcych w kapitałach ogółem o 6,65\%. W omawianym okresie dominująca pozycję w kapitałach obcych stanowiły zobowiązania krótkoterminowe, których udział w zobowiązaniach ogółem wynosił średnio $98,5 \%$.

W 2009 r. w porównaniu do roku ubiegłego nastapił dalszy wzrost wartości majątku o 16,3\%. W okresie tym znacznie szybciej zwiększył się majątek trwały (81\%), stąd też wzrósł jego udział w strukturze majatku z 20,05 do $31,19 \%$, co świadczy o poprawie bazy materialno-technicznej analizowanej spółki. W majątku obrotowym należy ocenić pozytywnie zmniejszenie udziału zapasów z 52,99 do 43,60\% oraz dalsze zmniejszenie udziału należności w majątku ogółem z 22,47 do 21,02\%. W tym okresie dynamika należności była jednak wyższa $(109,9 \%)$ aniżeli dynamika sprzedaży (102,56\%). Nastapił dalszy wzrost kapitałów własnych w stosunku do roku ubiegłego o 17,5\%, a ich udział w kapitałach ogółem wzrósł o dalsze 0,66 punktu procentowego. Dominujaca pozycję w kapitałach obcych, podobnie jak w poprzednich okresach, stanowiły zobowiązania krótkoterminowe. 


\begin{tabular}{|c|c|c|c|c|c|c|c|c|c|c|c|c|c|}
\hline \multirow{2}{*}{ 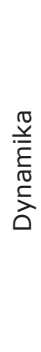 } & $\begin{array}{l}\infty \\
\stackrel{0}{N} \\
\stackrel{N}{o} \\
\stackrel{\sim}{N}\end{array}$ & $\begin{array}{l}0 \\
0 \\
-1 \\
\infty \\
-1\end{array}$ & $\begin{array}{l}\text { ㅅ } \\
\hat{0} \\
\text { - }\end{array}$ & $\begin{array}{l}0 \\
0 \\
\stackrel{-}{-} \\
-1\end{array}$ & $\begin{array}{l}8 \\
0 \\
0\end{array}$ & $\begin{array}{l}\stackrel{D}{2} \\
\text { ò } \\
\dot{+}\end{array}$ & $\begin{array}{l}\stackrel{2}{\text { مे }} \\
\text { ò }\end{array}$ & $\begin{array}{l}0 \\
\text { ㅇ- } \\
\text { - } \\
\text { - }\end{array}$ & $\begin{array}{l}\stackrel{2}{1} \\
\text { ñ }\end{array}$ & $\begin{array}{l}\text { ㅇ } \\
\text { ㅎ } \\
\text { 이 }\end{array}$ & $\begin{array}{l}0 \\
0 \\
0 \\
0 \\
0\end{array}$ & 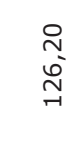 & $\begin{array}{l}0 \\
m \\
\sigma^{-} \\
\stackrel{-}{-1}\end{array}$ \\
\hline & $\begin{array}{l}\hat{o} \\
\stackrel{N}{1} \\
\infty \\
\stackrel{人}{0}\end{array}$ & $\begin{array}{l}0 \\
0 \\
0 \\
-7 \\
-1\end{array}$ & $\begin{array}{l}\infty \\
\infty \\
\infty \\
\infty\end{array}$ & $\begin{array}{l}\text { ○ } \\
\infty \\
\infty \\
\rightarrow \\
\rightarrow\end{array}$ & o & 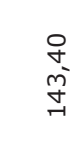 & $\begin{array}{l}8 \\
0 \\
\text { ने } \\
ન\end{array}$ & $\begin{array}{l}\text { m్ } \\
\text { స్ } \\
\text { - }\end{array}$ & $\begin{array}{l}\infty \\
\stackrel{\infty}{-} \\
\stackrel{m}{-}\end{array}$ & $\begin{array}{l}\text { 음 } \\
\text { - } \\
\stackrel{-}{-1}\end{array}$ & 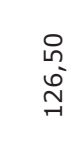 & $\begin{array}{l}\stackrel{8}{0} \\
i \\
\infty\end{array}$ & 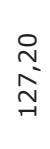 \\
\hline \multirow[b]{2}{*}{ ஓे } & 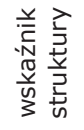 & $\begin{array}{l}\overrightarrow{2} \\
\vec{m}\end{array}$ & $\begin{array}{l}\stackrel{\operatorname{n}}{m} \\
0^{\prime}\end{array}$ & $\begin{array}{l}\text { ָे } \\
\text { Dे }\end{array}$ & 웅 & $\underset{-}{\stackrel{\sim}{N}}$ & $\begin{array}{l}0 \\
-1 \\
0 \\
0\end{array}$ & $\begin{array}{l}-1 \\
\infty \\
\infty \\
0\end{array}$ & $\begin{array}{l}\stackrel{8}{0} \\
\text { m̃ }\end{array}$ & $\begin{array}{l}\text { o } \\
\text { ì }\end{array}$ & $\stackrel{\infty}{\stackrel{\infty}{m}}$ & $\begin{array}{l}\vec{v} \\
0\end{array}$ & $\begin{array}{l}8 \\
8 \\
8 \\
\circ \\
-1\end{array}$ \\
\hline & $\begin{array}{l}\stackrel{\pi}{\xi} \\
\text { है }\end{array}$ & 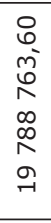 & 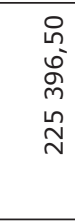 & 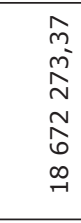 & $\begin{array}{l}0 \\
0\end{array}$ & $\begin{array}{l}8 \\
8 \\
0^{\circ} \\
0 \\
-1 \\
-1 \\
\sigma\end{array}$ & $\begin{array}{l}\text { n } \\
\text { ஸे } \\
\infty \\
\sigma \\
\sigma \\
\sigma\end{array}$ & 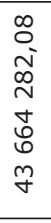 & 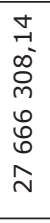 & $\begin{array}{l}0 \\
\stackrel{0}{0} \\
-1 \\
\infty \\
N \\
\tilde{m} \\
m \\
m\end{array}$ & $\begin{array}{l}\infty \\
-1 \\
-1 \\
\stackrel{N}{N} \\
\hat{N} \\
\text { r } \\
\sim\end{array}$ & 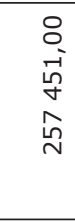 & 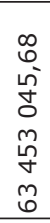 \\
\hline \multirow[b]{2}{*}{ 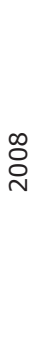 } & 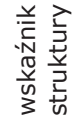 & $\begin{array}{l}\text { Ln } \\
\stackrel{\circ}{\text { v }}\end{array}$ & $\begin{array}{l}m \\
\stackrel{-}{0} \\
0\end{array}$ & $\begin{array}{l}\stackrel{\infty}{m} \\
\stackrel{\sim}{-}\end{array}$ & \& & $\begin{array}{l}\stackrel{n}{m} \\
0^{\prime}\end{array}$ & 웅 & $\begin{array}{l}\text { nू } \\
\text { oे }\end{array}$ & $\begin{array}{l}\text { gે } \\
\text { กิ }\end{array}$ & 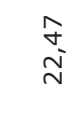 & $\begin{array}{l}\stackrel{\sim}{7} \\
\sim\end{array}$ & $\begin{array}{c}\hat{m} \\
\text { ó }\end{array}$ & $\begin{array}{l}\text { ㅇ } \\
\text { - } \\
\text { - }\end{array}$ \\
\hline & 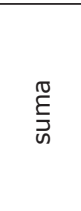 & 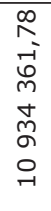 & $\begin{array}{l}-1 \\
\stackrel{N}{N} \\
\stackrel{+}{N} \\
m \\
\end{array}$ & 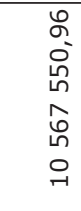 & $\begin{array}{l}8 \\
0 \\
0\end{array}$ & 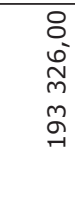 & 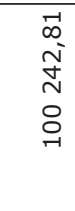 & 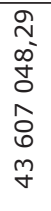 & $\begin{array}{l}\text { Na } \\
\text { Ṅ } \\
\text { N } \\
8 \\
o \\
\infty \\
\text { N }\end{array}$ & 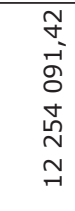 & $\begin{array}{l}\circ \\
\infty \\
\infty \\
\infty \\
\stackrel{N}{N} \\
\infty \\
\stackrel{\infty}{\sim} \\
\sim \\
\sim\end{array}$ & 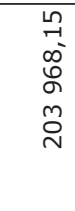 & 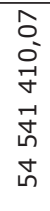 \\
\hline \multirow[b]{2}{*}{ } & 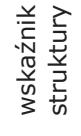 & $\stackrel{m}{m} \underset{N}{N}$ & $\begin{array}{l}\tilde{O} \\
0 \\
0\end{array}$ & $\begin{array}{l}0 \\
\infty \\
\text { i }\end{array}$ & $\begin{array}{l}8 \\
\text { ¿ }\end{array}$ & $\begin{array}{c}-1 \\
\vdots \\
0\end{array}$ & 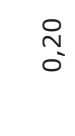 & $\begin{array}{l}\hat{0} \\
\infty^{-}\end{array}$ & $\begin{array}{l}\sigma \\
\sigma \\
\infty \\
+\end{array}$ & 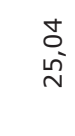 & $\begin{array}{l}\stackrel{2}{2} \\
\stackrel{-}{\sigma} \\
\end{array}$ & กิ & $\begin{array}{l}\text { 우 } \\
\text { - } \\
\text { - }\end{array}$ \\
\hline & 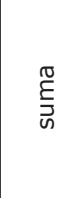 & 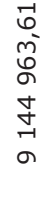 & 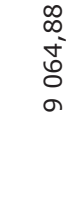 & 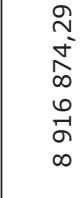 & \& & 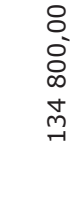 & 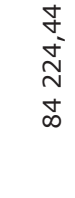 & 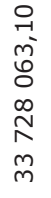 & 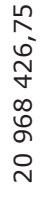 & 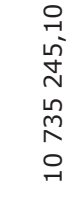 & $\begin{array}{l}\text { ñ } \\
\text { o } \\
\text { ก } \\
\hat{N} \\
\hat{N} \\
-1\end{array}$ & 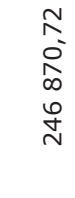 & 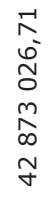 \\
\hline & 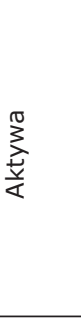 & 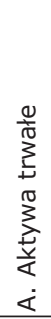 & 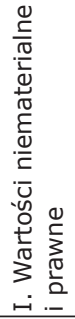 & 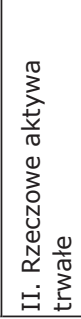 & 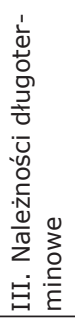 & 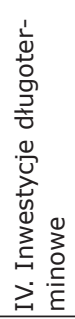 & 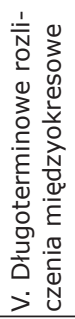 & $\begin{array}{l}0 \\
3 \\
0 \\
0 \\
0 \\
0 \\
0 \\
0 \\
3 \\
3 \\
\dot{0} \\
\dot{0} \\
\infty \\
0\end{array}$ & $\begin{array}{l}\text { ত } \\
\text { D } \\
0 \\
N \\
N \\
-\end{array}$ & 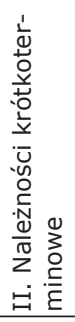 & 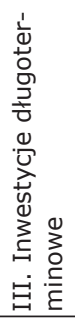 & 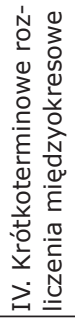 & 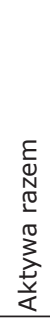 \\
\hline
\end{tabular}




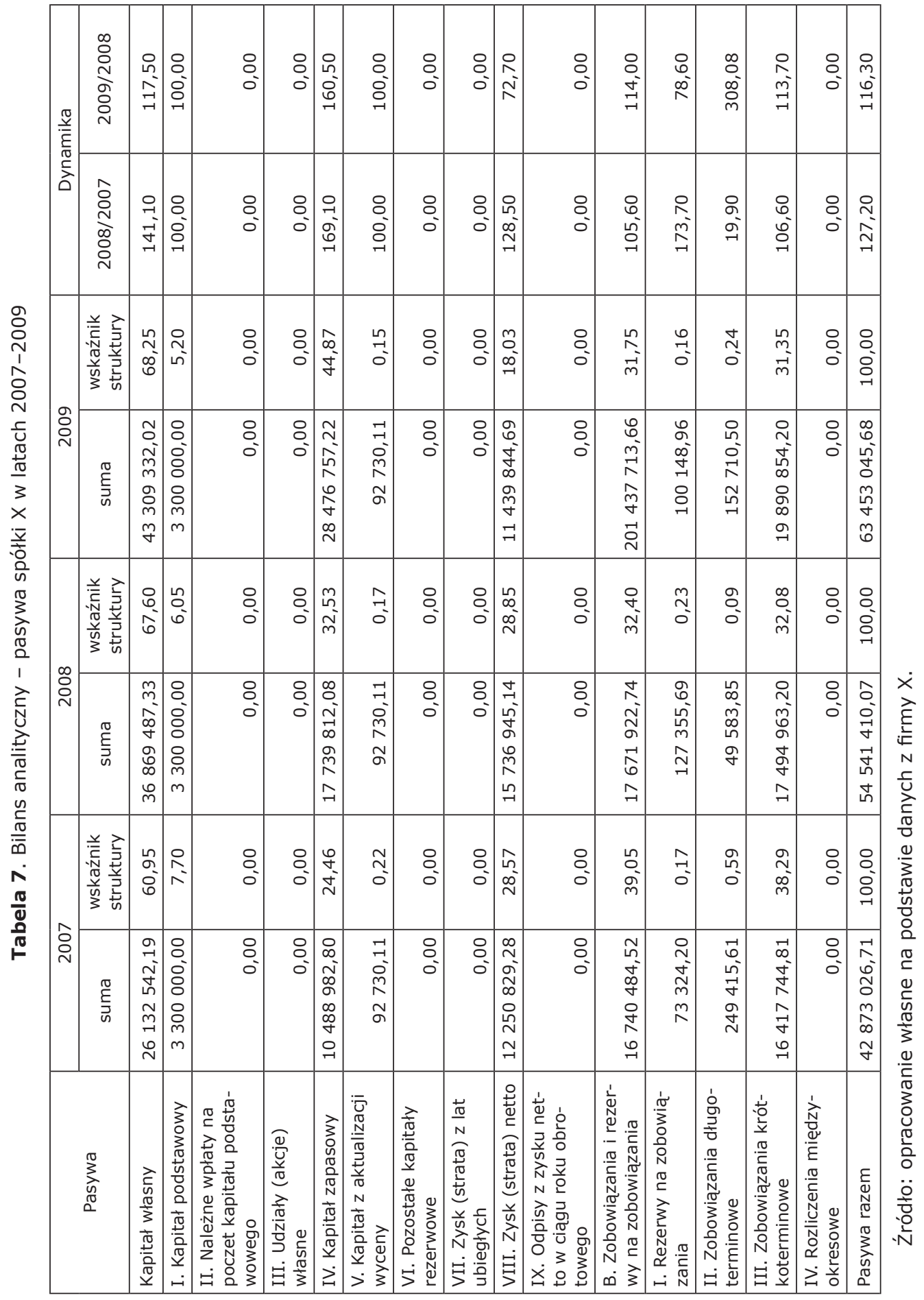


W omawianym okresie nastapił wzrost zobowiązań długoterminowych o $208 \%$, jednak ich udział w kapitałach ogółem w całym badanym okresie był niewielki i wahał się w granicach 0,09-0,59\%, co wynikało z wysokiego udziału kapitałów własnych w finansowaniu majątku.

Istotne znaczenie $w$ zakresie sytuacji majatkowo-finansowej ma dostosowanie struktury kapitału do struktury majatku. Finansowanie majatku w analizowanej spółce prezentuje tab. 8.

Tabela 8. Finansowanie majątku w spółce X w latach 2007-2009

\begin{tabular}{|l|c|c|c|}
\hline \multicolumn{1}{|c|}{ Wyszczególnienie } & 2007 & 2008 & 2009 \\
\hline Kapitał własny/majątek trwały & 2,86 & 3,37 & 2,19 \\
\hline Kapitał stały/majatek trwały & 2,88 & 3,38 & 2,20 \\
\hline Kapitał obcy/majątek trwały & 0,50 & 0,41 & 0,46 \\
\hline Wskaźnik ogólnej sytuacji finansowej & 5,72 & 8,14 & 4,76 \\
\hline
\end{tabular}

Źródło: opracowanie własne na podstawie danych z firmy $X$.

Z danych zawartych $w$ tab. 8 wynika, że w całym analizowanym okresie majatek trwały był w pełni finansowany kapitałem własnym. Zachowana więc została złota reguła bilansowa i finansowa. Ponadto kapitał własny finansował również znaczną część majątku obrotowego. Rozbieżność pomiędzy pierwszym a drugim wskaźnikiem jest niewielka, ze względu na mały udział zobowiązań długoterminowych w kapitałach ogółem. Wskaźnik ogólnej sytuacji finansowej był bardzo wysoki. Najwyższy poziom miał w 2008 r. W kolejnym okresie wskaźnik ten uległ zmniejszeniu, gdyż szybciej wzrastał majatek trwały aniżeli kapitał własny. Mimo to struktura finansowania majatku jest prawidłowa i spółka nie będzie miała problemów z płynnością finansowa.

\subsubsection{Analiza wstępna rachunku zysków i strat}

Analiza wstępna rachunku zysków i strat, zwana czytaniem tego sprawozdania, pozwala ustalić źródła tworzenia wyniku finansowego. Analityczny rachunek zysków i strat spółki X prezentuje tab. 9.

Z danych wynika, że w 2008 r. w porównaniu do roku ubiegłego przychody z podstawowej działalności wzrosły o 17,9\%, zaś koszty tej działalności minimalnie mniej, bo o $17,7 \%$, stąd też nastapił wzrost 


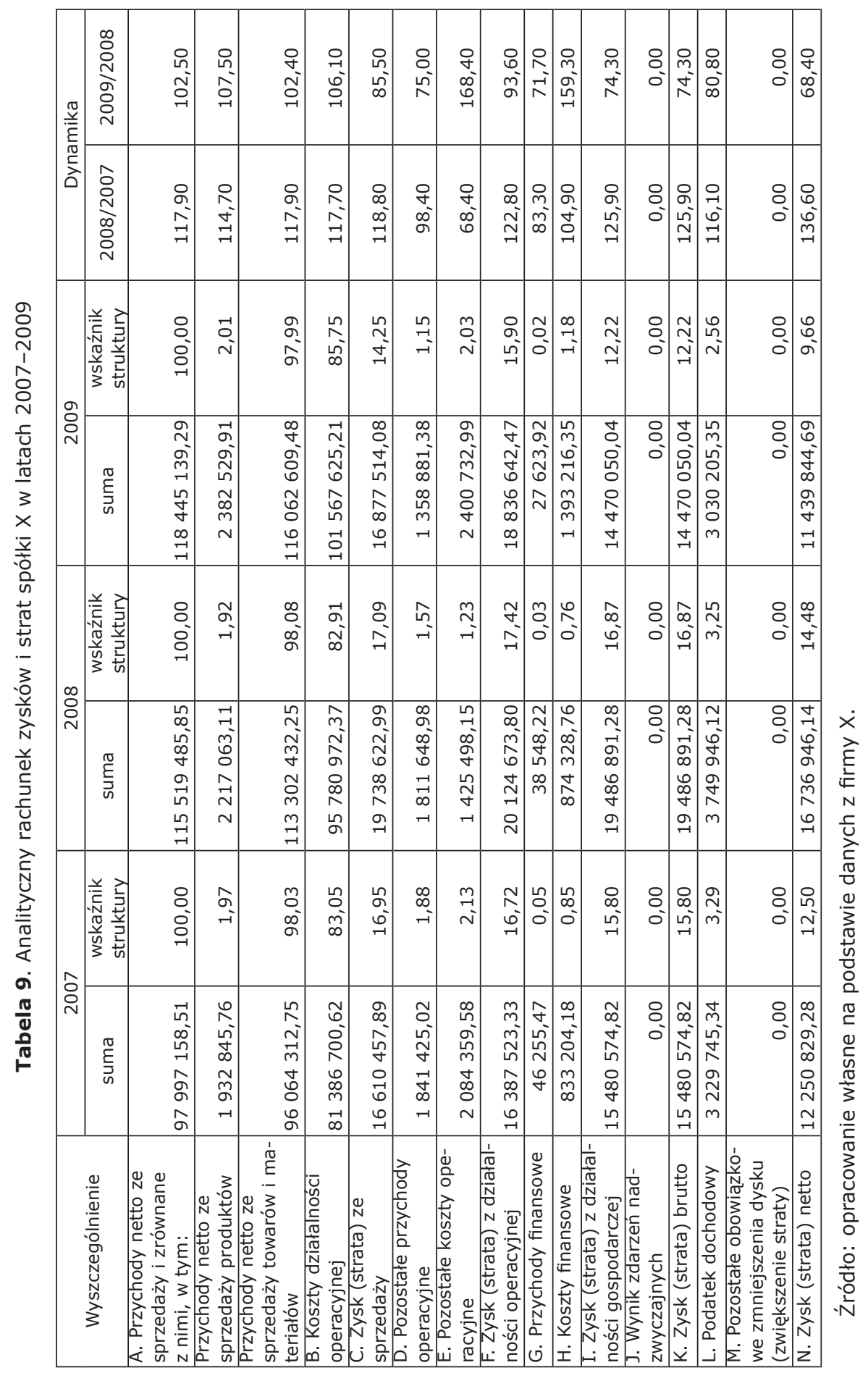


zysku na sprzedaży o 18,8\%, a jego udział w przychodach ze sprzedaży wzrósł o 0,14 punktu procentowego. Zmniejszeniu uległy pozostałe przychody i koszty operacyjne, a tym samym zmniejszył się ich udział w przychodach ze sprzedaży. W 2007 r. spółka na pozostałej działalności operacyjnej poniosła stratę, zaś w 2008 r. zysk wynoszący 386050,81 zł.

Udział przychodów i kosztów finansowych w przychodach ogółem również był niewielki. Na tej działalności oceniana spółka poniosła stratę. W całym badanym okresie nie wystapiły zdarzenia nadzwyczajne. W 2008 r. nastapił wzrost zysku netto o 4006 316,66 zł, co stanowiło $36,6 \%$.

W 2009 r. w porównaniu z rokiem ubiegłym nastapił wzrost przychodów z podstawowej działalności już tylko o 2,5\%, zaś koszty tej działalności wzrosły znacznie szybciej, bo o 6\%, co spowodowało zmniejszenie zysku na sprzedaży o 14,5\%. Pozostała działalność operacyjna, jak i działalność finansowa przyniosły straty. Stąd też wynik brutto był niższy niż wynik na podstawowej działalności. Po opłaceniu podatku dochodowego spółka osiągnęła zysk netto wynoszący 14470 050,04 zł, który był niższy od zysku w roku ubiegłym o 31,6\%.

Celem pogłębienia oceny dokonano analizy przychodów ze sprzedaży (tab. 10).

Tabela 10. Struktura przychodów ze sprzedaży w spółce X w latach 2007-2009

\begin{tabular}{|l|c|c|c|c|c|c|}
\hline \multirow{2}{*}{$\begin{array}{l}\text { Wyszcze- } \\
\text { gólnienie }\end{array}$} & \multicolumn{2}{|c|}{2007} & \multicolumn{2}{c|}{2008} & \multicolumn{2}{c|}{2009} \\
\cline { 2 - 7 } & suma & $\begin{array}{l}\text { wskaźnik } \\
\text { struktury }\end{array}$ & suma & $\begin{array}{l}\text { wskaźnik } \\
\text { struktury }\end{array}$ & suma & $\begin{array}{l}\text { wskaźnik } \\
\text { struktury }\end{array}$ \\
\hline $\begin{array}{l}\text { Przycho- } \\
\text { dy netto ze } \\
\text { sprzedaży } \\
\text { i zrównane } \\
\text { z nimi }\end{array}$ & 97997158,51 & 98,11 & 115519485,40 & 98,42 & 118445139,30 & 98,84 \\
\hline $\begin{array}{l}\text { Pozostałe } \\
\text { przychody } \\
\text { operacyjne }\end{array}$ & 1841425,02 & 1,84 & 1811648,98 & 1,54 & 1358881,38 & 1,13 \\
\hline $\begin{array}{l}\text { Przychody } \\
\text { finansowe }\end{array}$ & 46255,47 & 0,05 & 38548,22 & 0,04 & 27623,92 & 0,03 \\
\hline $\begin{array}{l}\text { Przychody } \\
\text { razem }\end{array}$ & 99884839,00 & 100,00 & 117369682,60 & 100,00 & 119831644,60 & 100,00 \\
\hline
\end{tabular}

Źródło: opracowanie własne na podstawie danych z firmy $\mathrm{X}$.

Z danych zawartych w tab. 10 wynika, że przychody z podstawowej działalności stanowiły dominująca pozycję w przychodach ogółem, ich udział w badanym okresie wynosił średnio 98,46\%. Udział pozosta- 
łych przychodów operacyjnych stanowił średnio 1,5\%, zaś przychodów finansowych zaledwie 0,04\%.

Strukturę kosztów badanej spółki prezentuje tab. 11.

Tabela 11. Struktura kosztów spółki X w latach 2007-2009

\begin{tabular}{|l|r|r|r|r|r|r|}
\hline \multirow{2}{*}{$\begin{array}{l}\text { Wyszczegól- } \\
\text { nienie }\end{array}$} & \multicolumn{2}{|c|}{2007} & \multicolumn{2}{c|}{2008} & \multicolumn{2}{c|}{2009} \\
\cline { 2 - 7 } & suma & $\begin{array}{l}\text { wskaźnik } \\
\text { struktury }\end{array}$ & suma & $\begin{array}{l}\text { wskaźnik } \\
\text { struktury }\end{array}$ & suma & $\begin{array}{l}\text { wskaźnik } \\
\text { struktury }\end{array}$ \\
\hline $\begin{array}{l}\text { Koszty } \\
\text { działalności } \\
\text { operacyjnej }\end{array}$ & 81386701,00 & 96,54 & 95780872,00 & 97,66 & 101567625,00 & 96,40 \\
\hline $\begin{array}{l}\text { Pozostałe } \\
\text { koszty } \\
\text { operacyjne }\end{array}$ & 92084360,00 & 2,47 & 1425498,20 & 1,45 & 2400733,00 & 2,28 \\
\hline $\begin{array}{l}\text { Koszty } \\
\text { finansowe }\end{array}$ & 833204,18 & 0,99 & 874328,75 & 0,89 & 1393216,40 & 1,32 \\
\hline $\begin{array}{l}\text { Koszty } \\
\text { ogółem }\end{array}$ & 84304264,00 & 100,00 & 98080699,00 & 100,00 & 105361575,00 & 100,00 \\
\hline
\end{tabular}

Źródło: opracowanie własne na podstawie danych z firmy $X$.

Z wyliczeń wynika, że koszty podstawowej działalności stanowiły średnio $96,87 \%$ kosztów ogółem, zaś pozostałe koszty operacyjne $2,07 \%$, a koszty finansowe $1,07 \%$.

Szczegółową analizę kosztów podstawowej działalności operacyjnej zawiera tab. 12 . Z przeprowadzonych obliczeń wynika, że dominująca pozycję w kosztach działalności podstawowej stanowiła wartość sprzedanych towarów i materiałów według rzeczywistych cen zakupu. Udział tej pozycji w kosztach działalności podstawowej zmniejszył się z 78,72\% w 2007 r. do 74,34\% w 2009 r., co wynikało z nieznacznego wzrostu sprzedaży w porównaniu do okresów poprzednich. Kolejną pozycja kosztów były wynagrodzenia, których udział wzrósł z 8,42\% w 2007 r. do 10,35\% w 2009 r. Udział pozostałych pozycji kosztów był niewielki; łącznie stanowił ok. 14\% kosztów podstawowej działalności operacyjnej.

Tabela 13 prezentuje strukturę wyniku finansowego. Analiza danych wskazuje, że badana spółka osiaggała zysk z działalności, do której została statutowo powołana. Inne działalności, czyli pozostała działalność operacyjna i działalność finansowa, przynosiły straty. 


\begin{tabular}{|c|c|c|c|c|c|c|c|c|c|c|}
\hline 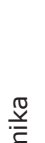 & 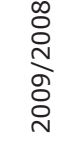 & $\begin{array}{l}\text { ᄋ } \\
0 \\
\stackrel{0}{-1}\end{array}$ & $\begin{array}{l}8 \\
\stackrel{0}{-} \\
\stackrel{-}{-1}\end{array}$ & $\begin{array}{l}\stackrel{D}{N} \\
\text { m } \\
\text { - }\end{array}$ & $\begin{array}{l}\stackrel{0}{N} \\
\text { In } \\
\stackrel{-}{-1}\end{array}$ & $\begin{array}{l}\infty \\
\infty \\
0 \\
-1 \\
-1\end{array}$ & $\begin{array}{l}8 \\
\text { Oे } \\
\stackrel{-}{-1}\end{array}$ & $\begin{array}{l}0 \\
\text { N } \\
\text { No } \\
\text { - }\end{array}$ & 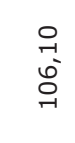 & $\begin{array}{l}0 \\
0 \\
\varnothing \\
-1\end{array}$ \\
\hline ठิ & 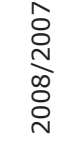 & $\begin{array}{l}\stackrel{0}{+} \\
\underset{-}{-} \\
-1\end{array}$ & $\begin{array}{l}0 \\
\infty \\
0 \\
\text { m } \\
\rightarrow-1\end{array}$ & $\begin{array}{l}\underset{N}{N} \\
\underset{\sim}{N}\end{array}$ & $\begin{array}{l}0 \\
\infty \\
\text { Nn } \\
0\end{array}$ & $\begin{array}{l}\text { q } \\
- \\
m \\
\stackrel{-1}{-}\end{array}$ & \begin{tabular}{l} 
m \\
$\underset{\sim}{N}$ \\
\multirow{-1}{N}{}
\end{tabular} & $\begin{array}{l}\text { O̊ } \\
\text { ó } \\
\text { - }\end{array}$ & $\begin{array}{l}\infty \\
\infty \\
\stackrel{-}{-} \\
\stackrel{-1}{-1}\end{array}$ & $\begin{array}{l}? \\
\text { i } \\
ت\end{array}$ \\
\hline & 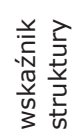 & $\stackrel{0}{+}$ & 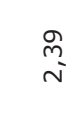 & $\begin{array}{l}\stackrel{L^{n}}{\text { ñ }^{\prime}}\end{array}$ & $\begin{array}{l}\sigma \\
\stackrel{1}{0} \\
0\end{array}$ & $\begin{array}{l}\stackrel{\nu}{m} \\
\text { O } \\
\stackrel{-}{-1}\end{array}$ & $\underset{N}{\stackrel{N}{N}}$ & 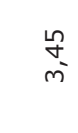 & $\begin{array}{l}\stackrel{+}{m} \\
\stackrel{N}{N}\end{array}$ & $\begin{array}{l}8 \\
\circ \\
0 \\
-1\end{array}$ \\
\hline 兑 & $\stackrel{\overbrace{}}{\tilde{E}}_{\mathfrak{n}}$ & $\begin{array}{l}\text { N } \\
\infty \\
\infty \\
\infty \\
N \\
\infty \\
\infty \\
\infty \\
+1 \\
-1\end{array}$ & 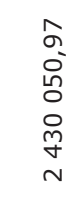 & 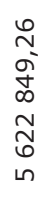 & 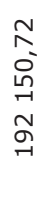 & 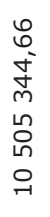 & 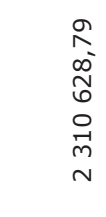 & 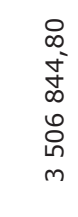 & 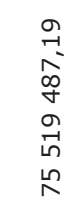 & 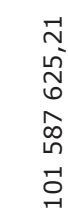 \\
\hline & 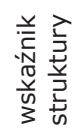 & $\stackrel{m}{\stackrel{m}{-}}$ & 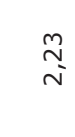 & 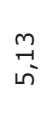 & $\begin{array}{l}\text { A } \\
\text { a- }\end{array}$ & $\begin{array}{l}\text { mे } \\
\text { o. }\end{array}$ & $\begin{array}{l}\hat{a} \\
\text { i }\end{array}$ & $\begin{array}{l}\infty \\
\stackrel{\infty}{m} \\
\stackrel{-1}{n}\end{array}$ & $\begin{array}{l}0 \\
\infty \\
0^{-}\end{array}$ & $\begin{array}{l}8 \\
\circ \\
0 \\
-1\end{array}$ \\
\hline 음 & $\stackrel{\overbrace{}}{\tilde{E}}_{\tilde{\omega}}$ & $\begin{array}{l}0 \\
\infty \\
0 \\
\iota^{-} \\
\infty \\
0 \\
0 \\
0 \\
-1\end{array}$ & 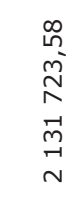 & 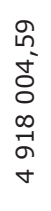 & 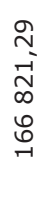 & $\begin{array}{l}\hat{0} \\
\hat{N} \\
\infty \\
-1 \\
\sigma \\
\infty\end{array}$ & 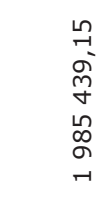 & 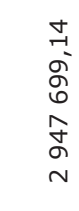 & $\begin{array}{l}0 \\
0 \\
0 \\
0 \\
0 \\
0 \\
\infty \\
0 \\
n \\
m \\
n\end{array}$ & 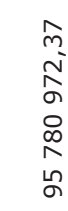 \\
\hline & 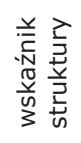 & $\begin{array}{l}0 \\
\stackrel{-1}{-1}\end{array}$ & $\begin{array}{l}8 \\
i\end{array}$ & $\begin{array}{l}\stackrel{\operatorname{n}}{\alpha} \\
\stackrel{\sigma}{-}\end{array}$ & $\begin{array}{l}\text { Oొ } \\
\stackrel{-}{0}\end{array}$ & $\underset{\infty}{\stackrel{N}{\infty}}$ & ब. & $\stackrel{n}{n}$ & $\begin{array}{l}N \\
\stackrel{N}{\infty} \\
\stackrel{0}{n}\end{array}$ & $\begin{array}{l}8 \\
0 \\
0 \\
-1\end{array}$ \\
\hline$\stackrel{\text { O }}{\text { D }}$ & $\begin{array}{l}\stackrel{\pi}{\xi} \\
\text { ڤ్ }\end{array}$ & 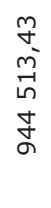 & 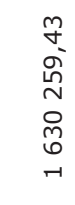 & 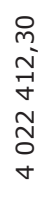 & 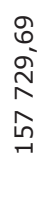 & $\begin{array}{l}n \\
\hat{N} \\
\text { n' } \\
+ \\
\overrightarrow{+} \\
\dot{y} \\
0 \\
0\end{array}$ & $\begin{array}{l}m \\
\infty \\
N \\
0 \\
0 \\
N \\
N \\
0 \\
-1\end{array}$ & 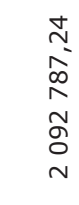 & 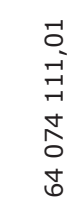 & 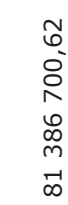 \\
\hline & 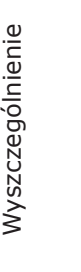 & 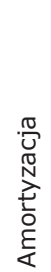 & 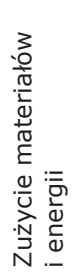 & 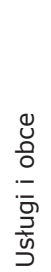 & $\begin{array}{l}\frac{\lambda}{0} \\
\frac{0}{0} \\
.0 \\
.- \\
\overline{0} \\
\frac{1}{0} \\
\frac{\pi}{0} \\
0\end{array}$ & $\begin{array}{l}\frac{\pi}{5} \\
\bar{N} \\
N \\
0 \\
0 \\
\frac{0}{0} \\
\stackrel{0}{5} \\
\vdots\end{array}$ & 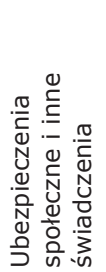 & 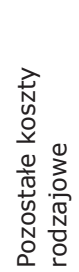 & 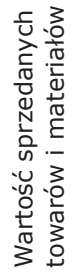 & 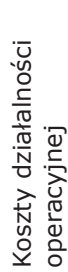 \\
\hline
\end{tabular}


Tabela 13. Struktura wyniku finansowego w spółce X w latach 2007-2009

\begin{tabular}{|c|c|c|c|c|c|c|}
\hline \multirow{2}{*}{$\begin{array}{l}\text { Wyszczegól- } \\
\text { nienie }\end{array}$} & \multicolumn{2}{|c|}{2007} & \multicolumn{2}{|l|}{2008} & \multicolumn{2}{|c|}{2009} \\
\hline & suma & $\begin{array}{l}\text { wskaźnik } \\
\text { struktury }\end{array}$ & suma & $\begin{array}{l}\text { wskaźnik } \\
\text { struktury }\end{array}$ & suma & $\begin{array}{l}\text { wskaźnik } \\
\text { struktury }\end{array}$ \\
\hline $\begin{array}{l}\text { Wynik na } \\
\text { sprzedaży }\end{array}$ & 16610457,89 & 107,20 & 19738622,99 & 101,29 & 16877514,09 & 116,63 \\
\hline $\begin{array}{l}\text { Wynik na } \\
\text { pozostałej } \\
\text { działalności } \\
\text { operacyjnej }\end{array}$ & 242934,56 & 1,47 & 386050,81 & 1,98 & 1041871,61 & 7,20 \\
\hline $\begin{array}{l}\text { Wynik na } \\
\text { działalności } \\
\text { finansowej }\end{array}$ & 886948,71 & 5,73 & 637782,54 & 3,27 & 1365592,43 & 9,43 \\
\hline $\begin{array}{l}\text { Wyniki } \\
\text { nadzwyczajne }\end{array}$ & 0,00 & 0,00 & 0,00 & 0,00 & 0,00 & 0,00 \\
\hline Wynik brutto & 15480574,62 & 100,00 & 19486891,28 & 100,00 & 14470050,04 & 100,00 \\
\hline
\end{tabular}

Źródło: opracowanie własne na podstawie danych z firmy $\mathrm{X}$.

\subsubsection{Czytanie rachunku przepływów pieniężnych}

Rachunek przepływów pieniężnych służy do dynamicznej oceny płynności finansowej. Analiza wstępna tego sprawozdania pozwala ustalić źródła generowania gotówki i kierunki jej wykorzystania.

Kształtowanie się przepływów pieniężnych w ramach poszczególnych rodzajów działalności w spółce X prezentuje tab. 14.

Tabela 14. Przepływy pieniężne w spółce X w latach 2007-2009

\begin{tabular}{|l|c|c|c|}
\hline \multicolumn{1}{|c|}{ Wyszczególnienie } & 2007 & 2008 & 2009 \\
\hline $\begin{array}{l}\text { Przepływy pieniężne } \\
\text { z działalności operacyjnej }\end{array}$ & 5572351,31 & 9162297,15 & 15157740,10 \\
\hline $\begin{array}{l}\text { Przepływy pieniężne } \\
\text { z działalności inwestycyjnej }\end{array}$ & 1752478,38 & 2811014,20 & 10022090,75 \\
\hline $\begin{array}{l}\text { Przepływy pieniężne } \\
\text { z działalności finansowej }\end{array}$ & 3279482,68 & 5898326,25 & 4993931,02 \\
\hline Przepływy pieniężne netto razem & 540390,25 & 452956,70 & 141718,33 \\
\hline
\end{tabular}

Źródło: opracowanie własne na podstawie danych z firmy X. 
W każdym analizowanym roku przepływy z tytułu podstawowej działalności były dodatnie, co zasługuje na pozytywną ocenę. Z kolei salda przepływów pieniężnych z działalności inwestycyjnej i finansowej były ujemne. Ujemne saldo z działalności inwestycyjnej świadczy o rozwoju spółki, w której to wydatki na wartości niematerialne i prawne przewyższaja wpływy z powyższych tytułów. Ujemne salda przepływów pieniężnych z działalności finansowej wynikaja z płatności dywidend na rzecz właścicieli, spłaty kredytów i zobowiązań z tytułu leasingu finansowego. Na pozytywna ocenę zasługuje dodatnie saldo przepływów netto ogółem, co oznacza, że wypracowana nadwyżka z działalności operacyjnej wystarcza na dalszy rozwój spółki oraz spłatę kredytów, zobowiązań i dywidendy dla właścicieli. Podkreślić należy, że z roku na rok wzrasta saldo przepływów gotówki z działalności operacyjnej, ale rosną również, w znacznie szybszym tempie, wydatki na inwestycje. Stąd też w porównaniu do lat poprzednich nastapiło zmniejszenie ogólnego salda przepływów.

Analizując przepływ gotówki, należy dokonać porównania przepływów pieniężnych z działalności operacyjnej z wynikiem finansowym netto (prezentuje to tab. 15).

Tabela 15. Wynik finansowy netto a salda przepływów pieniężnych z działalności operacyjnej w spółce X w latach 2007-2009

\begin{tabular}{|l|c|c|c|}
\hline \multicolumn{1}{|c|}{ Wyszczególnienie } & 2007 & 2008 & 2009 \\
\hline Wynik finansowy netto & 11439844,69 & 15736945,14 & 11439844,69 \\
\hline $\begin{array}{l}\text { Przepływy pieniężne } \\
\text { z działalności operacyjnej }\end{array}$ & 5572351,31 & 9162297,15 & 15157740,10 \\
\hline
\end{tabular}

Źródło: opracowanie własne na podstawie danych z firmy $\mathrm{X}$.

Spółka X osiągała w analizowanych latach zarówno dodatni wynik memoriałowy, jak i dodatni wynik kasowy. Analizowana spółka znajduje się więc w bardzo dobrej sytuacji finansowej. W 2009 r. wypracowana gotówka była nawet wyższa od zysku, co wynikało ze zmiany stanu zapasów i zobowiązań. 


\subsection{Analiza wskaźników przedsiębiorstwa logistycznego $X$}

\subsubsection{Ocena zdolności firmy do regulowania bieżących zobowiązań}

Analiza płynności dostarcza informacji do oceny zdolności spółki do regulowania zobowiązań w terminie. Dokonując analizy płynności finansowej, należy obliczyć i ocenić poziom kapitału pracującego w analizowanej spółce (przedstawia to tab. 16).

Tabela 16. Kapitał pracujący w spółce X w latach 2007-2009

\begin{tabular}{|l|r|r|r|}
\hline \multicolumn{1}{|c|}{ Wyszczególnienie } & 2007 & 2008 & 2009 \\
\hline \multicolumn{4}{|c|}{ Podejście majątkowe } \\
\hline Aktywa bieżące & 33728063,10 & 43607048,29 & 43664282,08 \\
\hline Zobowiązania bieżące & 16417744,81 & 17494983,20 & 19890854,20 \\
\hline Kapitał pracujący & 17310318,29 & 26112065,09 & 23773427,88 \\
\hline & Podejście kapitałowe & 100148,96 \\
\hline Kapitał własny & 26132542,19 & 36869487,33 & 43309332,02 \\
\hline Rezerwy długoterminowe & 73324,20 & 127355,69 & 152710,50 \\
\hline $\begin{array}{l}\text { Zobowiazania } \\
\text { długoterminowe }\end{array}$ & 249415,51 & 49583,85 & 43562191,48 \\
\hline Kapitał stały & 26455281,90 & 37046426,87 & 19788763,60 \\
\hline Majatek trwały & 9144963,61 & 10934361,78 & 23773427,88 \\
\hline Kapitał pracujący & 17310318,29 & 26112065,09 & 26 \\
\hline
\end{tabular}

Źródło: opracowanie własne na podstawie danych z firmy X.

W latach 2007-2009 kapitał pracujący był dodatni, co zasługuje na pozytywną ocenę. Najwyższy poziom osiagnął kapitał pracujacy w 2008 r. i wynosił 26112065,09 zł. W 2007 r. kapitał obrotowy netto wzrósł w porównaniu do 2007 r. o 37,34\%, natomiast w odniesieniu do roku ubiegłego uległ zmniejszeniu o $9 \%$. Zmniejszenie tegoż kapitału wynikało ze wzrostu zobowiązań bieżących o 13,7\%, przy prawie tym samym stanie aktywów bieżących. Wzrost zobowiązań bieżących był spowodowany tym, że zmniejszył się udział kapitałów długoterminowych w finansowaniu majątku obrotowego. Kapitały stałe za- 
angażowane zostały w finansowanie majątku trwałego, który wzrósł w porównaniu do roku ubiegłego o $81 \%$, przy wzroście kapitałów długoterminowych o $17,6 \%$.

Udział kapitału pracującego $\mathrm{w}$ finansowaniu majątku i w relacji do przychodów prezentuje tab. 17.

Tabela 17. Wskaźniki kapitału pracującego w spółce X w latach 2007-2009 (w \%)

\begin{tabular}{|l|c|c|c|}
\hline \multicolumn{1}{|c|}{ Wyszczególnienie } & 2007 & 2008 & 2009 \\
\hline Kapitał pracujący/aktywa ogółem $\times 100$ & 40,38 & 47,9 & 37,5 \\
\hline Kapitał pracujący/aktywa obrotowe $\times 100$ & 51,32 & 59,9 & 54,4 \\
\hline Kapitał pracujący/przychody ze sprzedaży $\times 100$ & 17,66 & 22,6 & 20,1 \\
\hline
\end{tabular}

Źródło: opracowanie własne na podstawie danych z firmy $\mathrm{X}$.

W analizowanym okresie udział kapitału pracującego $\mathrm{w}$ finansowaniu majątku ogółem wahał się w granicach 37,5-47,9\%, a w finansowaniu majątku obrotowego od 51,32 do 59,9\%. Najwyższy poziom osiagnęły omawiane wskaźniki w 2008 r. Ostatni ze wskaźników informuje, że na jedna złotówkę przychodów ze sprzedaży przypadło średnio 20,12 gr kapitału pracującego. Przy danej strategii finansowania działalności przedsiębiorstwa powinien wystapić proporcjonalny przyrost kapitału pracującego do przychodów ze sprzedaży. Statyczne mierniki płynności spółki X prezentuje tab. 18.

Tabela 18. Statyczne mierniki płynności

\begin{tabular}{|l|c|c|c|}
\hline \multicolumn{1}{|c|}{ Okres } & 2007 & 2008 & 2009 \\
\hline Wskaźnik bieżącej płynności (III) & 2,05 & 2,49 & 2,20 \\
\hline Wskaźnik płynności szybki (II) & 0,78 & 0,84 & 0,80 \\
\hline $\begin{array}{l}\text { Wskaźnik pokrycia zobowiazzań bieżących } \\
\text { środkami pieniężnymi (I) }\end{array}$ & 0,11 & 0,13 & 0,12 \\
\hline
\end{tabular}

Źródło: opracowanie własne na podstawie danych z firmy $X$.

Analiza danych wskazuje, że w spółce X wystapiła nieznaczna nadpłynność, gdyż wskaźnik bieżącej płynności przekraczał optymalny poziom $(1,5-2)$. Najwyższy poziom wskaźnik osiagnałł w 2008 r. Nadpłynność wynikała z nagromadzonych zapasów, co wynika z różnicy pomiędzy wskaźnikiem bieżącej płynności a wskaźnikiem płynno- 
ści szybkim. Różnica ta wynosiła średnio 1,44, czyli poziom zapasów był prawie równy dolnej granicy wskaźnika bieżącej płynności. Spółka nie będzie miała problemów ze spłatą bieżących zobowiązań, ale mało efektywnie wykorzystuje swój majatek obrotowy. Z kolei wskaźnik płynności szybki był poniżej optymalnych granic. Środki pieniężne były w stanie sfinansować zobowiązania bieżące średnio w 12\%, czyli poziom tego wskaźnika można uznać za zadowalający.

Pogłębieniem statycznych miar płynności jest dynamiczna ocena płynności dokonywana na podstawie rachunku przepływów pieniężnych (prezentuje to tab. 19).

Tabela 19. Wskaźniki wydajności i wystarczalności gotówkowej w spółce $X$ w latach 2007-2009

\begin{tabular}{|l|r|r|c|}
\hline \multicolumn{1}{|c|}{ Wyszczególnienie } & 2007 & 2008 & 2009 \\
\hline Wskaźnik wydajności gotówkowej sprzedaży & 0,06 & 0,08 & 0,13 \\
\hline Wskaźnik wydajności gotówkowej majątku & 0,13 & 0,17 & 0,24 \\
\hline Wskaźnik wydajności gotówkowej zysku & 0,36 & 0,47 & 0,24 \\
\hline $\begin{array}{l}\text { Wskaźnik wystarczalności gotówki operacyjnej } \\
\text { na spłatę długów ogółem }\end{array}$ & 0,33 & 0,52 & 0,75 \\
\hline $\begin{array}{l}\text { Wskaźnik wystarczalności gotówki operacyjnej } \\
\text { na spłatę długów długoterminowych }\end{array}$ & 22,34 & 184,78 & 99,26 \\
\hline
\end{tabular}

Źródło: opracowanie własne na podstawie danych z firmy X.

Wskaźnik wydajności gotówkowej sprzedaży z roku na rok ulega poprawie. W 2007 r. jedna złotówka sprzedaży przynosiła 6 gr gotówki, w 2008 r. 8 gr, a w 2009 r. już 13 gr gotówki. Rośnie również wskaźnik wydajności gotówkowej majątku. Jedna złotówka majątku przynosiła w 2007 r. 13 gr gotówki, zaś w 2009 r. już 24 gr.

Poprawie uległ także wskaźnik wydajności gotówkowej zysku. W latach 2007-2008 gotówka z działalności operacyjnej stanowiła średnio około $42 \%$ wypracowanego zysku z działalności gospodarczej. W 2009 r. gotówka kasowa przekraczała zysk memoriałowy. Gotówka wypracowana z działalności podstawowej była w stanie pokryć zobowiazania ogółem od 33 do 75\%, zaś zobowiązania długoterminowe przekraczała 102 razy.

Z przeprowadzonej oceny zarówno statycznych, jak i dynamicznych wskaźników płynności wynika, że sytuacja finansowa analizowanej spółki w zakresie zdolności płatniczej jest bardzo dobra. 


\subsubsection{Efektywność wykorzystania majątku w analizowanej firmie}

Z analizą płynności wiąże się ściśle analiza efektywności wykorzystania majatku. Poziom tych wskaźników w analizowanej spółce prezentuje tab. 20.

Tabela 20. Wskaźniki efektywności wykorzystania majątku w spółce $X$ w latach 2007-2009

\begin{tabular}{|l|r|r|r|}
\hline \multicolumn{1}{|c|}{ Wyszczególnienie } & 2007 & 2008 & 2009 \\
\hline Wskaźnik obrotowości aktywów & 2,60 & 2,41 & 2,03 \\
\hline Wskaźnik obrotowości aktywów trwałych & 11,27 & 11,69 & 7,80 \\
\hline Wskaźnik rotacji majątku obrotowego & 3,38 & 3,04 & 2,75 \\
\hline Wskaźnik rotacji zapasów w dniach & 63,92 & 77,71 & 85,99 \\
\hline Wskaźnik rotacji należności w dniach & 26,72 & 25,83 & 27,47 \\
\hline
\end{tabular}

Źródło: opracowanie własne na podstawie danych z firmy X.

Z analizy danych zawartych w tab. 20 wynika, że na jedną złotówkę majatku przypadało w badanym okresie przeciętnie 2,35 zł przychodów ze sprzedaży. Podkreślić należy, że z roku na rok efektywność majątku spółki $X$ ulega pogorszeniu. Wynika to z szybszego wzrostu majatku spółki aniżeli przychodów ze sprzedaży.

W 2008 r. w porównaniu z rokiem 2007 majątek ogółem wzrósł o 26,79\%, przy wzroście sprzedaży o 17,8\%. W następnym roku nastąpił dalszy wzrost majątku w porównaniu do roku ubiegłego o 21,13\%, podczas gdy sprzedaż wzrosła jedynie o ponad $2 \%$. Wskaźnik obrotowości aktywów trwałych uległ pogorszeniu z 11,27 w 2007 r. do 7,80 w 2009 r. Podobna sytuacja wystąpiła w zakresie rotacji majatku obrotowego, nastapiło zmniejszenie wskaźnika z 3,38 w 2007 r. do 2,75 w 2009 r. Wynikało to ze znacznego zwiększenia majątku - majatek trwały w 2008 r. w porównaniu do roku ubiegłego wzrósł o 13,28\%, a majatek obrotowy aż o 30,84\%. W 2009 r. w porównaniu do roku ubiegłego majątek trwały wzrósł o 53,01\%, a majątek obrotowy o 12,85\%.

Wydłużył się również czas obrotu zapasami. W 2007 r. zapasy zalegały w magazynie 64 dni, a w roku 2008 już 86 dni.

W 2008 r. w porównaniu do roku ubiegłego nastąpiła poprawa rotacji należności. W 2007 r. analizowana spółka ściagała należności od 
swoich odbiorców po 27 dniach, zaś w 2008 r. po 26 dniach. Spowodowane to zostało szybszym wzrostem sprzedaży $(17,8 \%)$ od wzrostu należności $(13,9 \%)$. W kolejnym roku windykacja należności od odbiorców uległa wydłużeniu i wynosiła 28 dni.

\subsubsection{Ocena stopnia wspomagania finansowego}

Analiza zadłużenia nie może być przeprowadzona przy pomocy liczb bezwzględnych, gdyż taka sama wartość kredytu ma inny wymiar finansowy w różnych przedsiębiorstwach. Stąd też do oceny zadłużenia należy wykorzystać wskaźniki, które określa, w jakim stopniu spółka $X$ finansuje swój majątek $z$ własnych źródeł, a w jakim ze źródeł zewnętrznych (tab. 21).

Tabela 21. Wskaźniki zadłużenia w spółce X w latach 2007-2009

\begin{tabular}{|l|r|r|r|}
\hline \multicolumn{1}{|c|}{ Wyszczególnienie } & \multicolumn{1}{|c|}{2007} & 2008 & 2009 \\
\hline Wskaźnik ogólnego zadłużenia & 0,390 & 0,320 & 0,320 \\
\hline $\begin{array}{l}\text { Wskaźnik udziału kapitału własnego } \\
\text { W finansowaniu majątku }\end{array}$ & 0,610 & 0,680 & 0,680 \\
\hline Wskaźnik relacji zobowiązań do kapitału własnego & 0,800 & 0,480 & 0,470 \\
\hline Wskaźnik zadłużenia długoterminowego & 0,009 & 0,001 & 0,004 \\
\hline $\begin{array}{l}\text { Wskaźnik majątku trwałego do zobowiązań } \\
\text { długoterminowych }\end{array}$ & 36,670 & 220,520 & 129,580 \\
\hline
\end{tabular}

Źródło: opracowanie własne na podstawie danych z firmy X.

Z przedstawionych danych wynika, że spółka X w 2007 r. finansowała swój majatek w $61 \%$ z kapitałów własnych, zaś w pozostałych dwóch latach wzrósł udział kapitałów własnych w finansowaniu majątku do $68 \%$, co świadczy o zwiększaniu się niezależności finansowej. Spółka zasilała kapitał własny z wypracowanego zysku. Stąd też zmniejsza się relacja zobowiązań do kapitałów własnych, a tym samym zmniejsza się ryzyko zarówno ze strony wierzycieli, jak i właściciela.

Udział zobowiązań długoterminowych $\mathrm{w}$ finansowaniu majątku w całym analizowanym okresie był bardzo niski (nie wynosił nawet $1 \%$ ). Wynikało to $z$ tego, że spółka posiadała wysoki stan kapitałów własnych. Stąd też wskaźnik zadłużenia długoterminowego jest bardzo niski. Ostatni z wyliczonych w tabeli wskaźników pokazuje, że spółka 


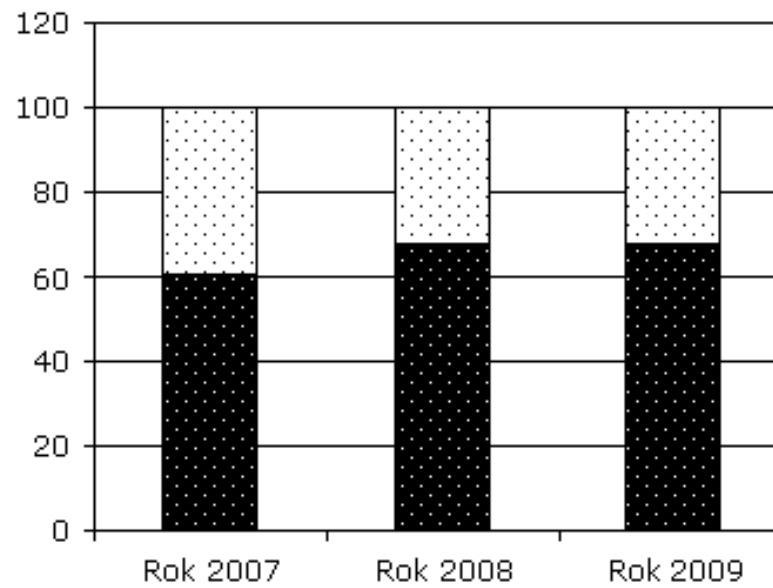

๑skaźnik ogólnego zadłużenia

- wskaźnik udziału kapitału whasnego w finansowaniu majątku

Wykres 1. Struktura finansowania majątku w analizowanej spółce Źródło: opracowanie własne

nie będzie miała problemów ze spłatą zobowiązań długoterminowych, a bank nie ponosi ryzyka kredytowego z tytułu udzielonego tej spółce kredytu.

\subsubsection{Analiza rentowności}

Wynik finansowy jako wartość absolutna nie za bardzo nadaje się do porównań. Stąd też istotne znaczenie mają wskaźniki rentowności. Wskaźniki rentowności sprzedaży informują o opłacalności sprzedaży. Poziom tych wskaźników w spółce X przedstawia tab. 22.

Tabela 22. Wskaźniki rentowności sprzedaży w spółce X w latach 2007-2009 (w \%)

\begin{tabular}{|l|c|c|c|}
\hline \multicolumn{1}{|c|}{ Wyszczególnienie } & 2007 & 2008 & 2009 \\
\hline Zysk ze sprzedaży/przychody ze sprzedaży × 100 & 16,95 & 17,09 & 14,25 \\
\hline $\begin{array}{l}\text { Zysk z działalności operacyjnej/przychody } \\
\text { ze sprzedaży + pozostałe przychody operacyjne } \times 100\end{array}$ & 16,41 & 17,15 & 15,72 \\
\hline $\begin{array}{l}\text { Zysk z działalności gospodarczej/przychody } \\
\text { ze sprzedaży + pozostałe przychody operacyjne } \\
+ \text { przychody finansowe }\end{array}$ & 15,50 & 16,60 & 12,08 \\
\hline $\begin{array}{l}\text { Zysk netto/przychody ze sprzedaży + pozostałe } \\
\text { przychody operacyjne + przychody finansowe }\end{array}$ & 12,26 & 14,26 & 9,55 \\
\hline
\end{tabular}

Źródło: opracowanie własne na podstawie danych z firmy $X$. 
W badanej spółce jedna złotówka sprzedanych produktów dała od 14,25 do 16,95 gr zysku na sprzedaży. Wskaźniki rentowności z całokształtu działalności były niższe niż rentowność działalności podstawowej ze względu na ponoszone straty na pozostałej działalności operacyjnej i działalności finansowej. Najwyższy poziom ROS (14,26\%) badana spółka osiagnnęła w 2008 r. W 2009 r. nastapiło obniżenie wskaźnika rentowności sprzedaży netto o 4,71 punktu procentowego.

Kolejna grupa wskaźników informuje o rentowności zaangażowanego majatku. Poziom tych wskaźników w ocenianej spółce prezentuje tab. 23.

Tabela 23. Wskaźniki rentowności majatku w spółce X w latach 2007-2009 (w \%)

\begin{tabular}{|l|r|r|c|}
\hline \multicolumn{1}{|c|}{ Wyszczególnienie } & 2007 & 2008 & 2009 \\
\hline Wskaźnik rentowności aktywów (ROA) & 31,89 & 34,36 & 19,39 \\
\hline Wskaźnik rentowności aktywów trwałych & 138,23 & 166,71 & 74,47 \\
\hline Wskaźnik rentowności aktywów obrotowych & 41,45 & 43,28 & 26,22 \\
\hline
\end{tabular}

Źródło: opracowanie własne na podstawie danych z firmy $\mathrm{X}$.

W pierwszych analizowanych latach rentowność majątku była dość wysoka i wynosiła 31,89\% w 2007 r., co oznacza, że jedna złotówka majątku przynosiła 31,89 gr zysku, a w 2008 r. o 2,47 gr więcej. W 2009 r. nastapiło znaczne obniżenie omawianego wskaźnika do $19,39 \%$. Wynikało to ze zmniejszenia zysku o $31,6 \%$ przy wzroście majatku o 53,01\%.

Pogorszeniu uległy również wskaźniki rentowności aktywów trwałych ze 166,71\% w 2008 r. do 74,47\% w 2009 r., a także rentowności aktywów obrotowych z 43,28\% w 2008 r. do 26,22\% w 2009 r.

Wskaźniki rentowności kapitałów własnych informuja o efektywności kapitału zainwestowanego przez właścicieli. Wskaźniki te dla analizowanej spółki pokazano w tab. 24.

Tabela 24. Wskaźniki rentowności kapitału w spółce X w latach 2007-2009 (w \%)

\begin{tabular}{|l|r|r|r|}
\hline \multicolumn{1}{|c|}{ Wyszczególnienie } & \multicolumn{1}{c|}{2007} & 2008 & \multicolumn{1}{c|}{2009} \\
\hline Wskaźnik rentowności kapitału własnego & 54,43 & 53,13 & 28,54 \\
\hline Wskaźnik rentowności kapitału podstawowego & 371,24 & 507,18 & 346,66 \\
\hline
\end{tabular}

Źródło: opracowanie własne na podstawie danych z firmy $\mathrm{X}$. 
Wyliczenia wskazuja, że jedna złotówka kapitału własnego w pierwszych dwóch analizowanych latach przynosiła średnio 53,78\% zysku, a w 2009 r. już tylko 28,54 gr. Tak znaczne obniżenie wskaźnika wynikało ze wspomnianego zmniejszenia zysku przy wzroście kapitału własnego o $27,3 \%$.

Rentowność kapitału podstawowego była najwyższa w 2008 r. i wynosiła 507,18\%, zaś najniższa w 2009 r., w którym to złotówka kapitału podstawowego przynosiła 3,47 zł zysku.

Dla pogłębienia badania rentowności spółki $X$ wykonano analizę Du Ponta (rys. 7).

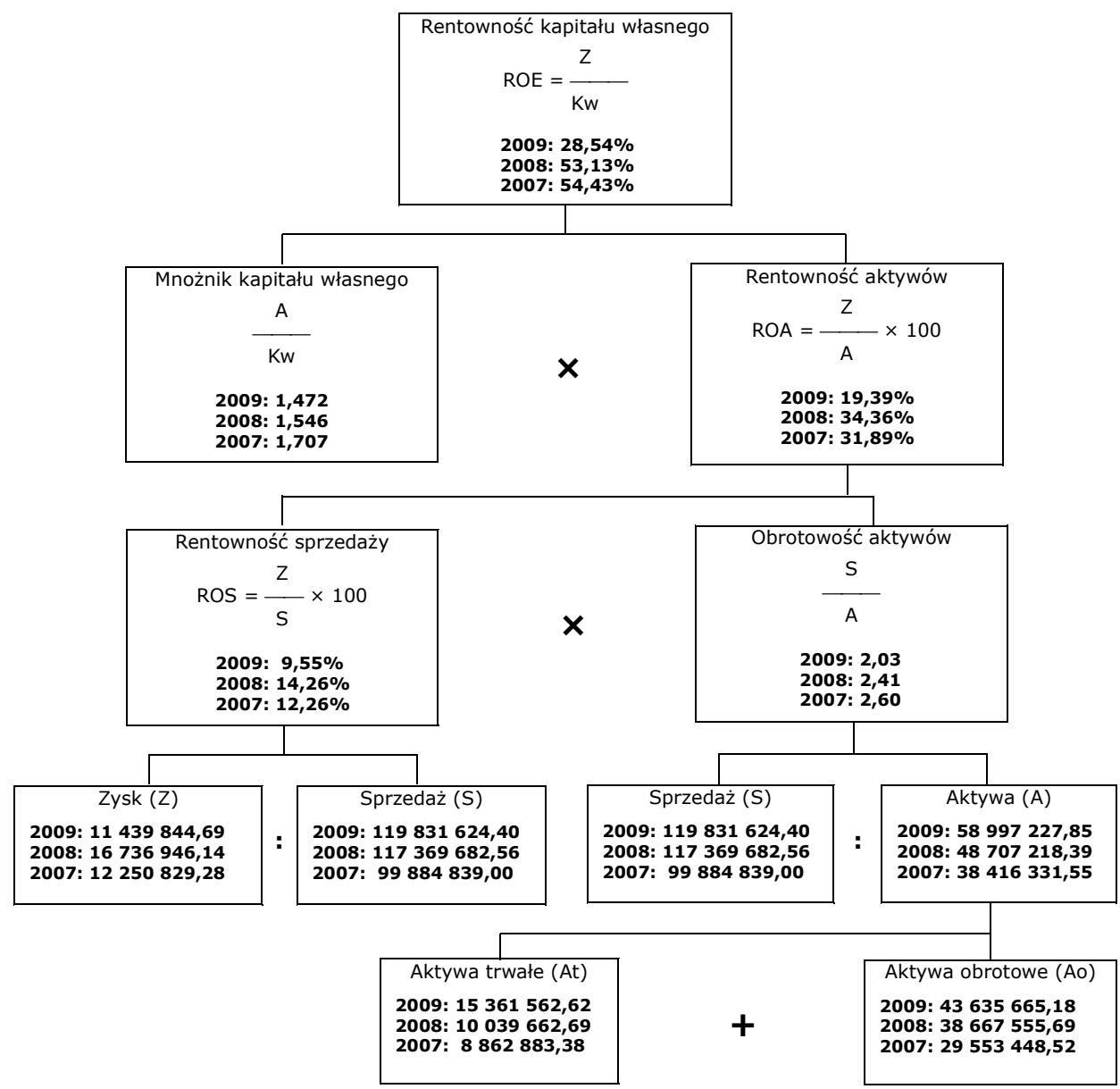

Rysunek 7. Analiza Du Ponta dla badanej firmy

Źródło: opracowanie własne 
Z analizy piramidalnej można wnioskować, że znaczne pogorszenie wskaźnika rentowności kapitału własnego wynikało z pogorszenia wskaźnika rentowności aktywów o 14,97\% oraz nieznacznego pomniejszenia mnożnika kapitału. Pogorszenie rentowności aktywów to skutek zarówno pogorszenia efektywności majątku, spowodowanej znacznym wzrostem majątku przy niewielkim wzroście sprzedaży, jak i pogorszenia rentowności sprzedaży.

\subsection{Podsumowanie}

W warunkach coraz szybciej zmieniającego się otoczenia, a w konsekwencji wzrostu niepewności i ryzyka w działalności przedsiębiorstwa, istotne znaczenie przypisuje się informacjom ekonomicznym, charakteryzującym zjawiska i zdarzenia gospodarcze. Ważną częścią składową informacji ekonomicznych sa informacje finansowe. Ujęte $w$ formie sprawozdań finansowych, prezentuja one syntetyczny obraz sytuacji majatkowej i finansowej przedsiębiorstwa oraz wyniki finansowe. Aby sprawozdania finansowe mogły stanowić przesłanki trafnych i szybkich decyzji zarządczych, muszą być poddawane okresowej analizie. Temu służy analiza finansowa, której treścia sa wielkości ekonomiczne w wyrażeniu pieniężnym ( $w$ odróżnieniu od analizy techniczno-ekonomicznej opartej na wielkościach ekonomicznych w wyrażeniu rzeczowym lub osobowym).

Analiza finansowa jest częścią składową rachunkowości, stanowi jej końcowy etap i dalsze rozwinięcie. Księgowy pracuje nad gromadzeniem i prezentowaniem danych o majatku, kapitale, przychodach, kosztach i wynikach. Analityk z kolei na ich podstawie ocenia sytuację przedsiębiorstwa, bada otoczenie i przygotowuje przesłanki do decyzji, jakie zostana podjęte przez kierownictwo firmy w przyszłości.

Źródłem informacji dla analizy finansowej (oceny kondycji finansowej) sa sprawozdania finansowe, które obejmują: bilans, rachunek zysków i strat oraz rachunek przepływów pieniężnych. Bilans przedstawia wielkości zasobowe (stan majatkowy i finansowy przedsiębiorstwa na określony dzień), natomiast rachunek zysków i strat prezentuje wielkości strumieniowe (poniesione w okresie sprawozdawczym koszty i straty oraz osiagnięte przychody i zyski).

Analiza finansowa jako narzędzie badania kondycji finansowej organizacji stanowi pewną procedurę badawczą, na którą składa się ana- 
liza wstępna sprawozdań finansowych oraz wskaźnikowa ocena sytuacji majątkowo-finansowej.

Analiza wstępna obejmuje dwa etapy: analizę pozioma, zwaną też analiza dynamiki (np. porównanie zmian w czasie poszczególnych pozycji aktywów i pasywów czy też przychodów i kosztów) oraz analizę pionowa, zwaną też analizą struktury (np. badanie struktury przychodów i kosztów).

Szczególnie dużo miejsca poświęcono wskaźnikowej ocenie sytuacji majątkowo-finansowej. Zaprezentowano wybrane wskaźniki objaśniające: płynność finansową firmy, efektywność wykorzystanego majatku (środków trwałych i obrotowych), źródła finansowania prowadzonej działalności (w tym zadłużenie przedsiębiorstwa), rentowność organizacji. Wskaźniki rentowności traktowane sa jako najbardziej syntetyczne mierniki oceny działalności gospodarczej. Na ich poziom wpływa całokształt zjawisk i procesów zachodzących w firmie. Stąd też analiza rentowności jest pewnym podsumowaniem i zwieńczeniem wcześniejszych analiz. Odpowiada na pytanie, czy funkcjonowanie przedsiębiorstwa jest opłacalne z punktu widzenia jego właścicieli.

W przypadku spółek giełdowych rynek kapitałowy przyczynia się do obiektywnej wyceny ich wartości rynkowej. Zatem wskaźniki rynku kapitałowego (zarówno wskaźniki wewnętrzne - ustalone na podstawie danych wewnętrznych przedsiębiorstwa, jak i wskaźniki zewnętrzne obliczone na podstawie danych o liczbie wyemitowanych akcji i ich cenie rynkowej) stanowia podstawę do oceny rentowności inwestycji kapitałowych w akcje spółek notowanych na giełdzie.

W niniejszym rozdziale podjęto próbę implementacji metodyki analizy finansowej do oceny kondycji majatkowo-finansowej konkretnej firmy. Ostatecznie zdecydowano się na wybór jednej z większych firm z sektora logistycznego, zlokalizowanej na terenie Łodzi. Co istotne, firma ta zdecydowała się udostępnić materiały źródłowe dotyczące jej finansów. Nie wyraziła jednak zgody na podanie nazwy oraz innych informacji, które mogłyby ją identyfikować. Dlatego też oznaczono ja litera $X$.

Oceny kondycji majatkowo-finansowej firmy dokonano w oparciu o dane pochodzące $z$ trzech podstawowych sprawozdań finansowych: z bilansu, rachunku zysków i strat oraz rachunku przepływów pieniężnych. Analizą objęto okres trzech lat, tj. lata 2007-2009.

Zgodnie z przyjęta procedurą badawcza, ocenę sytuacji finansowej firmy przeprowadzono na dwóch poziomach. Pierwszy to wstępna ana- 
liza sprawozdań finansowych (w ujęciu poziomym i poziomym), natomiast drugi to wskaźnikowa ocena sytuacji majatkowo-finansowej. Na podstawie badań można sformułować kilka wniosków:

- w badanej firmie w ostatnich latach miał miejsce rozwój jej bazy materialno-technicznej,

- kondycję finansową firmy należy ocenić pozytywnie,

- wzrasta udział kapitałów własnych w finansowaniu majątku przedsiębiorstwa, co świadczy o jego dużej niezależności finansowej,

- spółka nie ma problemów z bieżącym regulowaniem zobowiązań,

- firma jest rentowna. 